\title{
PENGARUH BEBERAPA METODE ISOLASI TERHADAP RENDEMEN DAN KARAKTERISTIK VIRGIN COCONUT OIL (VCO) SERTA APLIKASINYA PADA LOTION
}

\author{
The Effect of Isolation Methods on Yield and Characteristics of \\ Virgin Coconut Oil (VCO) and Its Application in Lotion
}

\author{
Putri Rizqi Amaliyah*, Tensiska, Efri Mardawati \\ Jurusan Teknologi Industri Pertanian - Fakultas Teknologi Industri Pertanian - Universitas Padjadjaran \\ Jl. Raya Bandung-Sumedang KM 21 Jatinangor, Sumedang 45363 Jawa Barat \\ *Penulis Korespondensi, email: putri16006@mail.unpad.ac.id
}

Disubmit: 17 Agustus 2020 Direvisi: 1 Oktober 2020 Diterima: 12 Oktober 2020

\begin{abstract}
ABSTRAK
Kelapa (Cocos nucifera) merupakan salah satu tanaman perkebunan yang banyak tumbuh di Indonesia dan memiliki banyak manfaat. Salah satu produk dari buah kelapa adalah Virgin Coconut Oil (VCO) yang dimanfaatkan menjadi bahan baku lotion. Krim lotion adalah bentuk emulsi setengah padat yang digunakan sebagai pelembab atau pemakaian pelindung pada kulit. Tujuan penelitian ini adalah menentukan metode isolasi VCO yang tepat, sehingga dihasilkan rendemen tertinggi dan karakteristik yang baik serta menentukan rasio antara VCO dan air yang tepat dalam pembuatan lotion. Penelitian tahap I, yaitu menentukan metode isolasi VCO terdiri atas empat perlakuan, yakni metode asam, metode enzimatis, metode pengocokan dengan mixer, dan metode sentrifugasi. Pengamatan pada VCO yang dihasilkan, yaitu rendemen, asam lemak bebas, dan kadar air. Penelitian tahap II, yaitu menentukan perbandingan VCO dan air, yaitu $0: 83,4 ; 2: 2,17 ; 2,25: 1,92 ; 2,5: 1,67 ; 2,75: 1,42$; dan 3:1,17. Pengamatan pada lotion meliputi uji homogenitas, uji stabilitas, uji $\mathrm{pH}$, bobot jenis, dan uji organoleptik. Pengujian karakteristik VCO dan lotion dilakukan analisis dengan ANOVA, dilanjutkan dengan uji Duncan dan uji Games Howell. Hasil penelitian menunjukkan metode isolasi pengocokan dengan mixer menghasilkan rendemen tertinggi, kadar air, dan asam lemak bebas yang memenuhi standar SNI, sehingga metode tersebut diaplikasikan dalam pembuatan lotion. Lotion yang memiliki nilai karakteristik mutu sesuai SNI dan organoleptik yang disukai adalah lotion dengan rasio penambahan VCO dan air 3:1,17 dengan nilai yang mendekati dengan lotion komersial
\end{abstract}

Kata kunci : Lotion; Sediaan Kosmetika; Virgin Coconut Oil (VCO)

\begin{abstract}
Coconut (Cocos nucifera) is a widely grown plantation crop in Indonesia and has many benefits. Products from coconut fruit are Virgin Coconut Oil (VCO) which can be used as a raw material for lotion. A lotion cream is a semi-solid emulsion that is used as a moisturizer or protective use on the skin. The purpose of this study is to determine the right method of isolating VCO with the highest yield value and good characteristics are produced, determining a ratio between VCO and water that is appropriate for lotion. Phase I, determine the isolation method of VCO that consisted of four treatments, namely the acidic method, enzymatic method, stirring with mixer method, and centrifugation method. Analysis of the VCO produce is determining yield, water content, and free fatty acids. Phase II, determine the ratio of VCO and water are 0:83,4; 2:2,17; $2,25: 1,92 ; 2,5: 1,67 ; 2,75: 1,42 ;$ and $3: 1,17$. Analysis of lotions is homogeneity tests, stability tests, $p H$, specific gravity, and organoleptic tests. Testing the characteristics of VCO and lotion was analyzed by ANOVA, continued with the Duncan test and Games Howell test. The results showed that the method of stirring isolation with mixer produced the highest yield, water content, and free fatty acids by SNI standards, so the method was applied in making lotions. Lotions that have quality characteristics according to SNI and organoleptic preferred are lotions with a ratio of VCO and water additions 3:1,17, because that value closes to commercial lotions
\end{abstract}

Keywords : Cosmetics; Lotion; Virgin Coconut Oil 


\section{PENDAHULUAN}

Tanaman kelapa di Indonesia memiliki potensi yang cukup tinggi terutama buahnya yang bisa diolah menjadi Virgin Coconut Oil (VCO), sebelum berkembangnya minyak sawit di sekitar akhir tahun 1980-an, minyak goreng dihasilkan dari buah kelapa atau kopra. Semenjak berdirinya industri pengolahan minyak sawit, industri VCO mengalami kemunduran yang drastis dan makin lama makin sulit ditemukan di pasaran. Buah kelapa pemanfaatannya hanya terbatas sebagai peng-hasil santan baik santan cair maupun bubuk. Hal ini sangat disayangkan, karena VCO memiliki beberapa kelebihan, yaitu mengandung asam lemak rantai sedang berupa asam laurat yang berfungsi sebagai sumber energi instan maupun sebagai anti virus dan sebagainya (Novarianto dan Tulalo, 2007). Selain digunakan untuk mencegah terjadinya penguapan air pada kulit, VCO juga berfungsi untuk menjaga kelembaban dan menghaluskan kulit (Sihombing et al., 2016).

Produksi VCO melalui beberapa tahapan yaitu pemarutan daging buah kelapa, mengisolasi santan yang merupakan emulsi minyak dalam air, dan isolasi minyak. Selain mengandung minyak, daging buah kelapa juga mengandung protein dan vitamin yang larut dalam minyak serta senyawa lain yang bermanfaat salah satunya antioksidan, seperti tokoferol dan betakaroten yang berfungsi untuk mencegah penuaan dini dan menjaga vitalitas tubuh (Setiadji dan Prayugo, 2006). Ketika dalam bentuk santan atau emulsi, minyak masih bersatu dengan air, karena adanya senyawa pengemulsi, yaitu protein. Umumnya proses isolasi minyak ini dilakukan dengan pemanasan santan, sehingga protein terdenaturasi (Mujdalipah, 2016). Namun untuk mencegah kerusakan bioaktif pada VCO, proses pengolahan dengan pemanasan dihindari, sehingga dihasilkan minyak yang diistilahkan dengan Virgin Coconut Oil (VCO) (Anwar dan Salima, 2016). Salah satu faktor yang mempengaruhi rendemen dalam produksi VCO adalah metode isolasi. Produksi VCO dapat dilakukan dengan beberapa metode, yaitu metode pengasaman, enzimatis, sentrifugasi, dan pengocokan dengan mixer (Muharun dan Apriyanto, 2014). Metode produksi dapat berpengaruh pada warna, tingkat ketengikan, waktu pembuatan, dan daya simpan (Anwar dan Salima, 2016). Metode isolasi pengasaman dilakukan dengan menambahkan asam asetat ke dalam santan dengan $\mathrm{pH}$ optimum yang sesuai untuk mendenaturasikan protein. Metode enzimatis adalah metode isolasi yang merusak ikatan lemak dengan mengganggu stabilitas protein pada santan menggunakan enzim proteolitik (Muharun dan Apriyanto, 2014). Metode sentrifugasi adalah metode isolasi mekanik yang mengganggu stabilitas protein menggunakan cara pemusingan gaya sentrifugal. Metode pengocokan dengan mixer, prinsipnya sama dengan sentrifugasi dengan berbeda kecepatan putarnya (Sukartin dan Sitanggang, 2005; Widiandani et al., 2010).

VCO dapat dijadikan bahan baku kosmetik, yaitu lotion. Produk yang dihasilkan harus sesuai dengan SNI dan preferensi konsumen, seperti aroma khas kelapa, kejernihan, dan dapat mempertahankan kelembaban kulit. Krim lotion adalah bentuk emulsi se-tengah padat yang digunakan sebagai emolien atau pemakaian dan pelindung pada kulit. Bentuk sediaan ini dapat mempermudah dalam proses penyebaran pada kulit, sehingga pemakaiannya merata, cepat, mudah dibersihkan, murah, aman, dan tidak toksik. Emulsi yang dibuat memiliki syaratsyarat yang perlu dipenuhi agar tidak terjadi hal berbahaya, yaitu mudah dioleskan merata pada kulit, mudah dicuci bersih, tidak menodai pakaian, tidak tengik dan iritasi, bebas partikulat keras dan tajam, serta harus homogen dan stabil (Ansel, 2008). Formulasi optimum untuk lotion VCO adalah jika sediaan yang dihasilkan memiliki sifat fisik dan stabilitas fisik yang sesuai dengan persyaratan mutu lotion (Nour et al., 2009).

Berdasarkan uraian di atas, maka perlu dilakukan penelitian tentang pengaruh metode isolasi terhadap rendemen dan karak-teristik VCO serta karakteristik lotion sebagai produk aplikasinya.

\section{METODE}

Bahan utama yang digunakan pada penelitian ini adalah buah kelapa tua yang didapatkan di Jatinangor, Kabupaten Sumedang, akuades, asam asetat, kulit buah pepaya, tween 80 , asam stearat, gliseril monostearat, setil alkohol, trietanolamin, span 80, asam benzoat, natrium metabisulfit, serta minyak atsiri almond. Peralatan yang diguna- 
kan pada penelitian ini adalah alat sentrifugasi, mixer, baskom plastik, parutan/mesin parutan, saringan, toples, dan waterbath.

\section{Metode Penelitian \\ Isolasi VCO dengan Beberapa Metode}

Produksi VCO dimulai dengan persiapan bahan baku, yaitu pengupasan kulit buah kelapa menggunakan mesin parut dan pemerasan parutan kelapa yang sebelumnya sudah ditambahankan akuades pada perbandingan parutan kelapa:akuades, yaitu $1: 1,3$. Hasil perasan didiamkan selama 2 jam hingga terbentuk 2 lapisan krim dan skim. Metode asam dilakukan penambahan asam asetat 25\% hingga $\mathrm{pH} 4.0$, kemudian diaduk selama 2 menit (Permatasari et al., 2015). Me-tode enzimatis dilakukan penambahan enzim kasar papain sebanyak 30\% (Barlina dan Torar, 2010). Metode pengocokan dengan mixer dilakukan dengan pengadukan selama 2 jam kecepatan putar sedang (Dali et al., 2015). Metode sentrifugasi dilakukan selama 15 menit pada sentrifugasi dengan kecepatan 1500 rpm (Raharja dan Dwiyuni, 2008). Hasil masing-masing metode didiamkan selama 24 jam sampai terbentuk tiga lapisan, yaitu blondo, minyak, dan air. Selanjutnya minyak dipisahkan dengan cara disaring dan menggunakan corong pisah.

VCO yang diperoleh dianalisis rendemen, asam lemak bebas, dan kadar air (Badan Standarisasi Nasional, 2008). Hasil analisis diolah menggunakan ANOVA dengan taraf signifikan 5\% yang dilanjutkan dengan uji Duncan Multiple Range Test dan uji Games Howell.

\section{Pembuatan Lotion}

Hasil VCO terbaik digunakan untuk pengaplikasian pada lotion. Pembuatan lotion mengacu pada metode Hasibuan (2011) diawali dengan pembuatan fase A melakukan pencampuran asam stearat, setil alkohol, gliseril monostearat, dan VCO di atas waterbath pada suhu $50^{\circ} \mathrm{C}$. Lakukan pembuatan fase B secara terpisah dengan mencampurkan asam benzoat, natrium metabisulfit, dan trietanolamin di atas waterbath pada suhu $50^{\circ} \mathrm{C}$. Campurkan kedua fase tersebut selama 15 menit. Hasil pencampuran ditambahkan span 80 dan tween 80 di atas waterbath pada suhu 50 ${ }^{\circ} \mathrm{C}$ selama 15 menit sampai terbentuk emulsi, kemudian tambahkan minyak atsiri almond.

Pada produk lotion dilakukan analisis homogenitas, stabilitas, uji $\mathrm{pH}$, bobot jenis, dan organoleptik (Badan Standarisasi Nasional, 1996; Departemen Kesehatan Republik Indonesia, 1979). Hasil analisis diolah menggunakan ANOVA dengan taraf signifikan 5\% uji Duncan Multiple Range Test.

\section{HASIL DAN PEMBAHASAN}

\section{Rendemen}

Rendemen VCO dihitung berdasarkan berat VCO yang dihasilkan per berat santan dikalikan dengan 100\% (Tabel 1) dan bertujuan untuk mengetahui efisiensi dari proses produksi. Berdasarkan Tabel 1 didapatkan bahwa rendemen VCO tertinggi menggunakan metode sentrifugasi dan tidak berbeda nyata dengan metode pengocokan dengan mixer. Analisis statistika menunjukkan bahwa perbedaan metode isolasi memberikan pengaruh yang berbeda nyata terhadap nilai rendemen.

Perbedaan hasil dapat dipengaruhi oleh perlakuan pada isolasi VCO. Metode sentrifugasi dan pengocokan menggunakan mixer merupakan metode fisik dalam merusak sistem emulsi dipandang lebih efisien dibandingkan dengan metode kimia maupun enzimatis dalam mendenaturasikan protein. Denaturasi protein adalah proses pemecahan yang mengubah sifat protein alaminya yang disebabkan dari perubahan kimia, fisik, dan biologi (Lukmana, 1976).

Beberapa penelitian lain menghasilkan rendemen yang berbeda, yaitu pada metode asam sebesar 27\% (Susanto, 2012), metode enzimatis sebesar 26\% (Barlina dan Torar, 2010), metode sentrifugasi sebesar 22\% (Raharja dan Dwiyuni, 2008), dan metode pengocokan dengan mixer sebesar $18 \%$ (Dali et al., 2015). Perbedaan hasil penelitian dapat dipengaruhi dari varietas kelapa dan tingkat pemerasan santannya.

Tabel 1. Nilai rendemen VCO

\section{No. Metode Isolasi Rendemen (\%)}

$\begin{array}{cll}\text { 1. } & \text { Asam } & 0,715 \pm 0,001^{\mathrm{a}} \\ \text { 2. } & \text { Enzimatis } & 0,808 \pm 0,000^{\mathrm{a}} \\ \text { 3. } & \text { Sentrifugasi } & 5,161 \pm 0,000^{\mathrm{b}} \\ \text { 4. } & \text { Mixer } & 4,992 \pm 0,006^{\mathrm{b}}\end{array}$

Keterangan: huruf yang sama menunjukkan nilai yang tidak berbeda nyata pada taraf 5\% 


\section{Kadar Air}

Kadar air merupakan salah satu hal penting sebagai kontrol kualitas VCO, karena keberadaan air dalam minyak akan mengakibatkan reaksi hidrolisis yang menyebabkan minyak berbau tengik dimana minyak berubah menjadi senyawa keton (Ansel, 2008). Berdasarkan Tabel 2 bahwa metode pengocokan dengan mixer memiliki nilai paling rendah dibandingkan metode lainnya. Analisis statistik menghasilkan bahwa setiap metode tidak memberikan pengaruh yang berbeda nyata.

Nilai kadar air maksimal pada SNI adalah 0,2 . Kadar air yang rendah pada metode pengocokan dengan mixer disebabkan dari tidak adanya proses penambahan bahan lainnya dan terjadi secara alami, sehingga tidak mengalami hidrolisis dibandingkan metode enzimatis dan kimia. Kadar air yang tinggi dapat dipercepat proses hidrolisisnya dengan adanya faktor panas, air, keasaman, dan enzim (Susanti et al., 2015).

Beberapa penelitian lain menghasilkan kadar air yang berbeda, yaitu pada metode asam sebesar 0,23\% (Susanto, 2012), metode enzimatis sebesar 0,1\% (Barlina dan Torar, 2010), metode sentrifugasi sebesar $0,02 \%$ (Raharja dan Dwiyuni, 2008), dan metode pengocokan dengan mixer sebesar 0,17\% (Dali et al., 2015). Perbedaan hasil penelitian dapat dipengaruhi dari proses penyaringan yang belum sempurna saat pengambilan minyak tersebut air ikut bercampur. Tingginya kadar air VCO disebabkan selama proses penyaringan yang belum sempurna, karena masih menggunakan kain kasa, kapas, dan kertas saring dimana air ikut bersama minyak, akibatnya kadar air VCO meningkat (Rahayu, 2006).

Tabel 2. Nilai kadar air VCO

\begin{tabular}{clc}
\hline No. & Metode Isolasi & Kadar Air $(\% \mathrm{db})$ \\
\hline 1. & Asam & $0,4545 \pm 0,003^{\mathrm{a}}$ \\
2. & Enzimatis & $0,191 \pm 0,001^{\mathrm{a}}$ \\
3. & Sentrifugasi & $0,367 \pm 0,001^{\mathrm{a}}$ \\
4. & Mixer & $0,120 \pm 0,000^{\mathrm{a}}$
\end{tabular}

Keterangan: huruf yang sama menunjukkan nilai yang tidak berbeda nyata pada taraf $5 \%$

\section{Asam Lemak Bebas}

Asam lemak bebas (ALB) atau Free Fatty Acids (FFA) merupakan salah satu parameter kerusakan minyak dari proses hidrolisis dari sejumlah air, enzim, maupun dari aktivitas mikroorganime yang dapat mempengaruhi flavor minyak (Nodjeng et al., 2013). Berdasarkan Tabel 3 bahwa metode pengocokan mixer memiliki nilai paling rendah dibandingkan metode lainnya. Analisis statistika menunjukkan bahwa masing-masing metode memberikan pengaruh yang berbeda nyata.

Nilai asam lemak bebas pada SNI adalah maksimal 5. Nilai asam lemak bebas yang rendah pada metode pengocokan dengan mixer disebabkan dari tidak adanya proses penambahan bahan lainnya dan terjadi secara alami, sehingga tidak mengalami hidrolisis dibandingkan metode enzimatis dan kimia. Kadar asam lemak bebas yang tinggi dapat dipercepat proses hidrolisisnya dengan adanya faktor panas, air, keasaman, dan enzim (Susanti et al., 2015).

Beberapa penelitian lain menghasilkan kadar air yang berbeda, yaitu pada metode asam sebesar 0,4\% (Susanto, 2012), metode enzimatis sebesar $0,12 \%$ (Barlina dan Torar, 2010), metode sentrifugasi sebesar 0,3\% (Raharja dan Dwiyuni, 2008), dan metode pe-ngocokan dengan mixer sebesar $0,26 \%$ (Dali et al., 2015). Hal lainnya yang dapat berpengaruh pada nilai kadar air adalah proses penyaringan yang belum sempurna dimana saat pengambilan minyak tersebut air ikut bercampur. Keberadaan air pada santan juga menyebabkan proses hidrolisis, sehingga asam lemak bebas bernilai tinggi (Nodjeng et al., 2013).

Berdasarkan hasil pengujian VCO, didapatkan bahwa metode isolasi paling efektif dengan nilai rendemen tertinggi adalah

Tabel 3. Nilai asam lemak bebas VCO

\begin{tabular}{clc}
\hline No. & Metode Isolasi & $\begin{array}{c}\text { Asam Lemak } \\
\text { Bebas (\%) }\end{array}$ \\
\hline 1. & Asam & $0,927 \pm 0,000^{\mathrm{a}}$ \\
2. & Enzimatis & $5,220 \pm 0,006^{\mathrm{d}}$ \\
3. & Sentrifugasi & $1,665 \pm 0,000^{\mathrm{c}}$ \\
4. & Mixer & $0,674 \pm 0,001^{\mathrm{b}}$ \\
\hline
\end{tabular}

Keterangan: huruf yang sama menunjukkan nilai yang tidak berbeda nyata pada taraf $5 \%$ 
metode sentrifugasi dan metode pengocokan dengan mixer yang hasilnya tidak berbeda nyata. Peninjauan dari pengujian lainnya bahwa metode pengocokan dengan mixer sesuai dengan SNI dan menghasilkan rendemen yang tinggi. Hal ini akan membantu untuk membuat VCO lebih banyak agar lebih efisien untuk pengaplikasiannya pada lotion.

\section{Homogenitas}

Pengujian homogenitas pada lotion bertujuan untuk melihat penyebaran bahanbahan yang digunakan dalam formulasi lotion ditunjukkan pada Tabel 4. Pada sediaan lotion yang diuji homogenitas tidak terdapat butiran-butiran pada kaca bening, maka sediaan lotion tersebut dikatakan homogen.

Seluruh formulasi memberikan hasil yang sama dan tidak terdapat perbedaan pengaruh yang signifikan. Sediaan dengan formula A, B, C, D, E, dan F ini tidak menghasilkan butiran-butiran, sehingga dapat dikatakan homogen. Hal tersebut baik suhu dan waktu pencampuran yang sesuai, yaitu suhu $50{ }^{\circ} \mathrm{C}$ dan waktu pencampuran 15 menit.

\section{Stabilitas}

Sediaan lotion dalam pengujian stabilitas selama 8 minggu tidak terjadi perubahan warna, aroma, dan konsistensi selama penyimpanan. Sediaan emulsi dikatakan tidak

Tabel 4. Pengujian homogenitas lotion

\begin{tabular}{ccc}
\hline No. & $\begin{array}{c}\text { Rasio VCO } \\
\text { dan Air }\end{array}$ & Homogenitas \\
\hline 1. & $0: 83,4$ & Tidak Ada Butiran \\
2. & $2: 2,17$ & Tidak Ada Butiran \\
3. & $2,25: 1,92$ & Tidak Ada Butiran \\
4. & $2,5: 1,67$ & Tidak Ada Butiran \\
5. & $2,75: 1,42$ & Tidak Ada Butiran \\
6. & $3: 1,17$ & Tidak Ada Butiran \\
\hline
\end{tabular}

Tabel 5. Pengukuran pH sediaan lotion

\begin{tabular}{ccc}
\hline No. & Rasio/Ratio & $\mathbf{p H}$ \\
\hline 1. & $0: 83,4$ & 5 \\
2. & $2: 2,17$ & 5 \\
3. & $2,25: 1,92$ & 5 \\
4. & $2,5: 1,67$ & 5 \\
5. & $2,75: 1,42$ & 5 \\
6. & $3: 1,17$ & 5 \\
\hline
\end{tabular}

stabil saat terjadi koalesensi, flokulasi, dan creaming. Formula tersebut dikatakan stabil dan tidak merusak hasil produknya.

Terdapat beberapa faktor yang mempengaruhi kestabilan emulsi pada lotion, yaitu faktor mekanis, temperatur, dan proses pembentukan emulsi (Purwaningsih et al., 2014). Hasil pengujian stabilitas pada minggu ke-1 dan minggu ke-8 ditunjukkan pada Gambar 1 .

\section{Uji pH}

Penentuan $\mathrm{pH}$ sediaan lotion ini menggunakan $\mathrm{pH}$ indikator. Pengujian $\mathrm{pH}$ dimaksudkan agar saat penggunaannya tidak mengiritasi kulit, stabilitas sediaan, dan efektifitasnya dimana sesuai dengan SNI berkisar 4,5-8,0 (Fajriyah et al., 2010).

Tabel 5 menunjukkan bahwa $\mathrm{pH}$ seluruh sediaan formulasi sesuai dengan SNI dan stabil selama 8 minggu. Hal ini disebabkan dari bahan-bahan yang digunakan sama dan aman, serta lotion tersebut stabil. Kestabilan $\mathrm{pH}$ dapat mencegah kerusakan produk selama penyimpanan dimana apabila $\mathrm{pH}$ di bawah 4,5 akan dapat mengiritasi kulit, sedangkan apabila $\mathrm{pH}$ di atas 8,0 akan menyebabkan kulit menjadi bersisik dan kering (Tranggono dan Latifah, 2013).

Tabel 6. Perbandingan nilai dan uji lanjut Duncan bobot jenis lotion

\begin{tabular}{lcc}
\hline No. & Rasio & Bobot Jenis \\
\hline 1. & $0: 83,4$ & $1,11 \pm 0,013^{\mathrm{a}}$ \\
2. & $2: 2,17$ & $1,02 \pm 0,019^{\mathrm{b}}$ \\
3. & $2,25: 1,92$ & $0,99 \pm 0,0371^{\mathrm{bc}}$ \\
4. & $2,5: 1,67$ & $1,00 \pm 0,045^{\mathrm{bc}}$ \\
5. & $2,75: 1,42$ & $0,98 \pm 0,41^{\mathrm{c}}$ \\
6. & $3: 1,17$ & $0,99 \pm 0,003^{\mathrm{bc}}$ \\
\hline
\end{tabular}

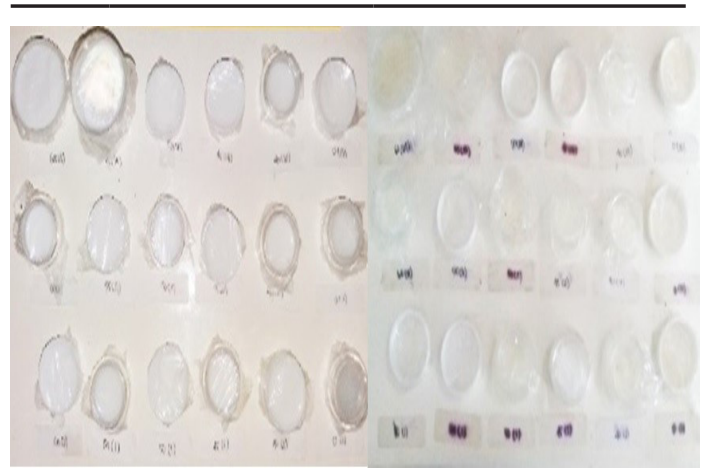

Gambar 1. Hasil pengujian stabilitas 


\section{Bobot Jenis}

Pengujian bobot jenis menggunakan piknometer dengan melakukan penimbangan piknometer kosong dan piknometer yang sudah terisi dimana prinsipnya didasarkan atas penentuan massa cairan dan penentuan ruang yang ditempati cairan tersebut.

Berdasarkan Tabel 6 bahwa nilai bobot jenis lotion yang paling terkecil adalah rasio VCO dan air 2,75:1,42 dan paling terbesar adalah rasio $\mathrm{VCO}$ dan air 0:83,4. Analisis statistika menunjukkan bahwa rasio $\mathrm{VCO}$ dan air 0:83,4 dengan formulasi lainnya memiliki perbedaan secara signifikan, sedangkan pada kombinasi formulasi lainnya tidak memiliki perbedaan secara signifikan dalam memberikan pengaruh terhadap bobot jenis.

Standar SNI untuk nilai bobot jenis adalah 0,95-1,05, sehingga hasil pengujian bahwa semua formula sediaan lotion hasil pengujian bobot jenis memenuhi standar yang berlaku terkecuali rasio VCO dan air 0:83,4. Pengaruh perbedaan nilai bobot jenis disebabkan oleh bobot jenis air lebih berat dari VCO, sehingga semakin tinggi penambahan VCO akan semakin rendah nilai bobot

Tabel 7. Organoleptik tekstur lotion

\begin{tabular}{clcc}
\hline No. & Rasio & Nilai & Keterangan \\
\hline 1. & Komersial & $5,87^{\mathrm{a}}$ & Suka \\
2. & $0: 83,4$ & $1,27^{\mathrm{c}}$ & Kurang Suka \\
3. & $2: 2,17$ & $1,80^{\mathrm{cd}}$ & Kurang Suka \\
4. & $2,25: 1,92$ & $1,93^{\mathrm{c}}$ & Kurang Suka \\
5. & $2,5: 1,67$ & $3,33^{\text {bc }}$ & Biasa \\
6. & $2,75: 1,42$ & $4,20^{\mathrm{b}}$ & Biasa \\
7. & $3: 1,17$ & $5,67^{\mathrm{a}}$ & Suka \\
\hline
\end{tabular}

Keterangan : huruf yang sama menunjukkan nilai yang tidak berbeda nyata pada taraf $5 \%$

Tabel 8. Organoleptik warna lotion

\begin{tabular}{clcc}
\hline No. & Rasio & Nilai & Keterangan \\
\hline 1. & Komersial & $4,8^{\mathrm{a}}$ & Suka \\
2. & $0: 83,4$ & $4,2^{\mathrm{b}}$ & Biasa \\
3. & $2: 2,17$ & $4,27^{\mathrm{b}}$ & Biasa \\
4. & $2,25: 1,92$ & $4,2^{\mathrm{b}}$ & Biasa \\
5. & $2,5: 1,67$ & $4,2^{\mathrm{bc}}$ & Biasa \\
6. & $2,75: 1,42$ & $4,27^{\mathrm{b}}$ & Biasa \\
7. & $3: 1,17$ & $4,4^{\mathrm{a}}$ & Suka \\
\hline
\end{tabular}

Keterangan: huruf yang sama menunjukkan nilai yang tidak berbeda nyata pada taraf $5 \%$ jenisnya. Bobot jenis juga dapat berpengaruh pada preferensi konsumen, karena tekstur dan daya oles yang dihasilkan.

\section{Organoleptik}

Pengujian organoleptik yang digunakan adalah uji mutu hedonik meliputi penilaian terhadap tekstur, warna, aroma, dan daya oles pada produk lotion komersial dan formulasi lotion penelitian ini dengan tingkat kesukaan mulai dari sangat tidak suka (1), tidak suka (2), agak tidak suka (3), netral (4), agak suka (5), suka (6), dan sangat suka (7) (Rahayu, 2001). Pengujian organoleptik mutu hedonik dilakukan oleh sukarelawan berjumlah minimal 12 orang yang memiliki beberapa kriteria, seperti wanita berbadan sehat, usia antara 20-25 tahun, tidak ada riwayat penyakit yang berhubungan dengan alergi, dan bersedia menjadi sukarelawan (Departemen Kesehatan Republik Indonesia, 1985).

Pada Tabel 7 terlihat data organoleptik hedonik dengan jumlah panelis sebanyak 15 orang. Berdasarkan Tabel 7, lotion komersil memiliki tekstur yang paling disukai oleh

Tabel 9. Organoleptik aroma lotion

\begin{tabular}{clcc}
\hline No. & Rasio & Nilai & Keterangan \\
\hline 1. & Komersial & $6,2^{\mathrm{a}}$ & Suka \\
2. & $0: 83,4$ & $2,067^{\mathrm{b}}$ & Biasa \\
3. & $2: 2,17$ & $2,067^{\mathrm{b}}$ & Biasa \\
4. & $2,25: 1,92$ & $2,133^{\mathrm{b}}$ & Biasa \\
5. & $2,5: 1,67$ & $2,2^{\mathrm{b}}$ & Biasa \\
6. & $2,75: 1,42$ & $2,2^{\mathrm{b}}$ & Biasa \\
7. & $3: 1,17$ & $2,332^{\mathrm{b}}$ & Biasa \\
\hline
\end{tabular}

Keterangan : huruf yang sama menunjukkan nilai yang tidak berbeda nyata pada taraf $5 \%$

Tabel 10. Organoleptik daya oles lotion

\begin{tabular}{clcc}
\hline No. & Rasio & Nilai & Keterangan \\
\hline 1. & Komersial & $6^{\mathrm{a}}$ & Suka \\
2. & $0: 83,4$ & $2,067^{\mathrm{c}}$ & Kurang Suka \\
3. & $2: 2,17$ & $4,8^{\mathrm{a}}$ & Suka \\
4. & $2,25: 1,92$ & $4^{\mathrm{bcd}}$ & Biasa \\
5. & $2,5: 1,67$ & $4,4^{\mathrm{b}}$ & Suka \\
6. & $2,75: 1,42$ & $4,2^{\mathrm{bc}}$ & Biasa \\
7. & $3: 1,17$ & $4,4^{\mathrm{b}}$ & Suka \\
\hline
\end{tabular}

Keterangan: huruf yang sama menunjukkan nilai yang tidak berbeda nyata pada taraf $5 \%$ 
Jurnal Teknologi Pertanian Vol. 21 No. 3 [Desember 2020] 203-210

Pengaruh Beberapa Metode Isolasi Terhadap Rendemen dan Karakteristik VCO [Amaliyah dkk]

panelis, karena memiliki tekstur yang lembut dan nyaman saat diaplikasikan pada kulit serta lotion dengan rasio VCO:air, 3:1,7 teksturnya mirip dengan lotion komersial.

Berdasarkan Tabel 8 pada parameter warna menunjukkan bahwa lotion komersial sama dengan lotion pada formulasi lainnya, karena menghasilkan warna putih yang sama disebabkan semua formulasi menggunakan bahan yang sama. Para panelis menunjukkan bahwa warna tidak terlalu memiliki pengaruh pada saat pemakaian lotion. Sementara Tabel 9 menunjukkan hasil hedonik pada parameter aroma menunjukkan bahwa lotion komersial menghasilkan aroma yang paling disukai oleh panelis, karena aromanya wangi dan tahan lama saat dioleskan. Sementara itu formulasi lainnya memiliki aroma yang tidak disukai oleh panelis, karena hanya aroma dari VCO yang keluar atau bahkan tidak ada aroma yang keluar. Aroma dari minyak atsiri almond sendiri tidak menghasilkan wangi almond, sehingga saat dicampurkan tidak keluar aromanya.

Pada Tabel 10 untuk parameter daya oles menunjukkan bahwa lotion komersil memiliki daya oles yang paling disukai oleh panelis, karena tidak lengket, tidak cair, dan cepat kering saat pengaplikasian pada kulit. Formulasi dengan rasio VCO dan air sebesar 2:2,17, 2,5:1,92, dan 3:1,17 beberapa panelis menyukainya, karena menghasilkan rasa yang sama saat diaplikasikan pada kulit, namun perbedaan konsentrasi ini menghasilkan konsistensi yang berbeda dimana ada panelis yang menyukai hasil yang lebih kental dan juga ada panelis yang menyukai hasil yang lebih cair.

\section{SIMPULAN}

Pada penelitian ini dapat disimpulkan bahwa metode isolasi yang menghasilkan rendemen tertinggi adalah pengocokan dengan sentrifugasi sebesar 5,16\%. Namun jika ditinjau dengan karakteristik lainnya maka metode pengocokan dengan mixer tidak berbeda nyata dengan metode sentrifugasi. Hasil rendemen pada metode dengan mixer adalah 4,99\%, kadar air sebesar 0,12\%, dan asam lemak bebas (ALB) sebesar 0,67\%. Rasio penambahan VCO dan air 3:1,71 menghasilkan lotion dengan karakteristik mutu sesuai SNI dan organoleptik hedonik dari kriteria tekstur, warna, dan daya oles disukai.

\section{DAFTAR PUSTAKA}

Ansel, HC. 2008. Pengantar Bentuk Sediaan Farmasi. UI Press, Jakarta

Anwar, -C., Salima, -R., 2016. Perubahan rendemen dan mutu virgin coconut oil (VCO) pada berbagai kecepatan putar dan lama waktu sentrifugasi. Jurnal Industri Teknologi Pertanian. 10(2), 52-61. https:/ / doi.org/10. 24198 /jt.vol10n2.1

Badan Standarisasi Nasional. 1996. SNI 164399-1996, Sediaan Tabir Surya.

Badan Standarisasi Nasional. 2008. SNI 7381:2018, Minyak Kelapa Murni (VCO).

Barlina, -R., Torar, D, -J., 2010. Pemanfaatan ekstrak enzim kasar papain dan bromelin pada pembuatan minyak starter dan pengaruhnya pada mutu virgin coconut oil (VCO) selama penyimpanan. Buletin Palma. 38, 1-9. https://doi. org/ 10.21082/bp.v11n38.2010.1-9

Dali, -A., La Harimu., Cinong Simbiti, -LM., 2015. Pengaruh kecepatan putar pengadukan dan waktu pendiaman terhadap rendemen dan kualitas minyak kelapa murni (VCO). Al Kimia. 3(1), 48-58. https://doi.org/10.24252/alkimia.v3i1. 1660

Departemen Kesehatan Republik Indonesia. 1979. Farmakope Indonesia (Edisi 3). Departemen Kesehatan Republik Indonesia

Departemen Kesehatan Republik Indonesia. 1985. Formularium Kosmetik Indonesia. Departemen Kesehatan Republik Indonesia

Fajriyah, -U., Astuti, I, -Y., Hartanti, -D., 2010. Formulasi losion ekstrak herba tali putri (Cuscuta australis R. Br.) dan aktivitas antioksidan secara in vitro. Pharmacy, Jurnal Farmasi Indonesia. 7(1), 24-34. https://doi.org/ 10.30595/pji.v7i1.542

Hasibuan, SS. 2011. Penggunaan Minyak Kelapa Murni (VCO) sebagai Pelembab dalam Sediaan Krim. Skripsi. Universitas Sumatera Utara. Medan

Lukmana, -A., 1976. Denaturasi protein. Bulletin Penelitian Kementerian Perindustrian Indonesia, 1(4). http://dx.doi. org/10.24817/jkk.v0i0.4853

Muharun, -M., Apriyanto, -M., 2014. Pengolahan minyak kelapa murni (VCO) dengan metode fermentasi menggunakan ragi tape merk NKL. Jurnal Teknologi Pertanian Universitas Islam Indragiri. 3(2), 9-14. https://doi.org/ $10.32520 /$ jtp.v3i2.69 
Jurnal Teknologi Pertanian Vol. 21 No. 3 [Desember 2020] 203-210

Pengaruh Beberapa Metode Isolasi Terhadap Rendemen dan Karakteristik VCO [Amaliyah dkk]

Mujdalipah, -S., 2016. Pengaruh ragi tradisional Indonesia dalam proses fermentasi santan terhadap karakteristik rendemen, kadar air, dan kadar asam lemak bebas virgin coconut oil (VCO). Edufortech. 1(1), 1-6. https://doi.org/ 10.175 09/edufortech.v1i1.3969

Nodjeng, -M., Fatimah, -F., Rorong, J, -A., 2013. Kualitas virgin cococnut oil (VCO) yang dibuat pada metode pemanasan bertahap. Jurnal Ilmiah Sains. 13(2), 102-109. https:// doi.org/10.35799/ jis.13.2.2013.3053

Nour, A, -H., Mohammed, F, -S., Yunus, R, -M., Arman, -A., 2009. Demulsification of virgin coconut oil by centrifugation method: A feasibility study. International Journal of Chemical Technology. 1(2), 59-64. https:/ / doi. org/10.3923 / ijct.2009.59.64

Novarianto, -H., Tulalo, -M., 2007. Kandungan asam laurat pada berbagai varietas kelapa sebagai bahan baku VCO. Jurnal Penelitian Tanaman Industri. 13(1), 28-33. http://dx.doi. org/10.21082/ jlittri.v13n1.2007.28-33

Permatasari, -S., Hastuti, -P., Setiaji, -B., Hidayat, -C., 2015. Sifat fungsional isolat protein "Blondo" (Coconut Presscake) dari produk samping pemisahan VCO (Virgin Coconut Oil) dengan berbagai metode. Agritech. 35(4), 441-448. https: //doi.org/10.22146/agritech.9328

Purwaningsih, -S., Salamah, -E., Budiarti, T, -A., 2014. Formulasi skin lotion dengan penambahan karagenan dan antioksidan alami dari Rhizophora mucronata Lamk. Jurnal Akuatika. 5(1), 55-62. http: / /jurnal.unpad.ac.id/akuatika/article/view/3705

Raharja, -S., Dwiyuni, -M., 2008. Kajian sifat fisiko kimia ekstrak minyak kelapa murni (Virgin Coconut Oil) yang dibuat dengan metode pembekuan krim santan. Jurnal Teknologi Industri Pertanian. 18(2), 71-78. https://journal.ipb. ac.id/index.php/jurnaltin/article/ view/4751
Rahayu, -T., 2006. Kualitas VCO berdasarkan kadar protein, kadar air, dan logam berat (Fe dan $\mathrm{Pb}$ ) berbagai produk VCO (Virgin Coconut Oil). Jurnal Penelitian Sains dan Teknologi. 7(1), 1-10. http:// hdl.handle. net/11617/386

Rahayu, WP. 2001. Penuntun Praktikum Penilaian Organoleptik. IPB. Bogor

Setiadji, B, Prayugo, S. 2006. Membuat VCO Berkualitas Tinggi. Penebar Swadaya. Jakarta

Sihombing, E, -R., Yuniarlina, -R., Supardi, -S., 2016. The effectiveness of back massage using virgin coconut oil and white petroleum jelly to prevent pressure sores. Jurnal Keperawatan Muhammadiyah. 1(2), 1-9. http://journal. um-surabaya.ac.id/index.php/JKM/ article/view/SHB

Sukartin, JK., Sitanggang, M. 2005. Gempur Penyakit Dengan VCO, $2^{\text {nd }}$ edition. Agro Media Pustaka. Jakarta

Susanti, N, M, -P., Widjaja, I, N, -K., Dewi, N, M, A, -P., 2015. Pengaruh waktu sentrifugasi krim santan terhadap kualitas virgin coconut oil (VCO). Jurnal Farmasi Udayana. 4(1), 4-7. https:/ / ojs. unud.ac.id/index.php/jfu/article/ view/15450

Susanto, -T., 2012. Kajian metode pengasaman dalam proses produksi minyak kelapa ditinjau dari mutu produk dan komposisi asam amino blondo. Jurnal Dinamika Penelitian Industri. 23(2), 124-130. http://dx.doi.org/10.28959/ jdpi.v23i2.616

Tranggono, RI, Latifah, F. 2013. Buku Pegangan Ilmu Pengetahuan Kosmetik. Penerbit Pustaka Utama. Jakarta

Widiandani, -T., Purwanto, Bambang, T, -P., Hardjono, -S., Susilowati, -R., Diyah, N, -W., 2010. Upaya peningkatan kualitas minyak kelapa yang dibuat dari Cocos nucifera L. dengan berbagai metode kimiawi dan fisik. Berkala Ilmiah Kimia Farmasi. 1(1), 1-6. http://journal.unair.ac.id/download-fullpapersPublikasi4_minyak@2010a.pdf 